\title{
Synthetic pathways to a family of pyridine-containing azoles - promising ligands for coordination chemistry
}

\author{
Vyatsheslav N. Nuriev, Nikolay V. Zyk, and Sergey Z. Vatsadze* \\ Organic Chemistry Chair, Chemistry Department, M. V. Lomonosov Moscow State University, \\ Leninskie Gory, Moscow, 119992, Russia \\ E-mail: szv@org.chem.msu.ru
}

Dedicated to Professor N. S. Zefirov on the occasion of his $70^{\text {th }}$ birthday

(received 11 May 05; accepted 13 Aug 05; published on the web 22 Aug 05)

\begin{abstract}
A series of pyridine-containing pyrazoles, isoxazoles, imidazoles, oxazoles, thiazoles, oxadiazoles, triazoles, and 1,3,4-triazepines were synthesized and characterized with the aim of their future study as conjugated building blocks for the construction of coordination compounds.
\end{abstract}

Keywords: Pyridine, azoles, coordination polymers

\section{Introduction}

The design of coordination polymeric frameworks with unique structures and valuable application properties is a topical area in comprehensive coordination and material chemistry. ${ }^{1,2}$ Many studies are concentrated on metal complexes based on pyridyl-bearing ligands. These ligands are represented by the general formula $\mathrm{Py}-\mathrm{X}-\mathrm{Py}$, where $\mathrm{X}$ is a conjugating unit between two exo-dentate pyridines. The simplest ligand of this type is $4,4^{\prime}$-bipyridyl, which is widely used in constructing coordination polymers. ${ }^{3}$ Typical $\mathrm{X}$ 's are $\mathrm{C}=\mathrm{C}$ and $\mathrm{C} \equiv \mathrm{C}$ bonds, azo- and imine-groups, benzene, triazine and tetrazine rings, or a combination of the fragments listed. ${ }^{4}$ Recently, several research groups published papers on the coordination ability of polydentate ligands based on five-membered azoles as a central linker between two pyridines. $5,6,7,8$

In this paper we describe our study on the synthesis and characterization of several groups of expanded bipyridines (Py-X-Py type molecules) based on a five-membered heterocyclic central fragment $\mathrm{X}$. We focused our efforts on pyridine-containing pyrazoles, isoxazoles, imidazoles, oxazoles, thiazoles, oxadiazoles, triazoles, and 1,3,4-triazepines. 


\section{Results and Discussion}

General synthetic routes to 1,2-azoles include the reaction of bis-nucleophiles with $\beta$-diketones. Pyridine-containing pyrazoles and isoxazoles are the most investigated class among pyridinecontaining azoles, which is due to the synthetic availability of various $\beta$-diketones. Using the known procedures for the synthesis of dipyridinepyrazoles 2a-2c, ${ }^{9}$ new aryl and donor-type hetaryl substituted pyrazoles 2d, 2e were synthesized (Scheme 1). The yields of the reactions are in good accordance with the electronic influence of the pyridine moiety, except for product 2c where the stability of the diketone is crucial for the yield. The approach shown is also valuable for the preparation of sym-isoxazole 3a, which could be easily isolated in moderate yield after heating of the appropriate $\beta$-diketone with hydroxylamine (see Scheme 1).

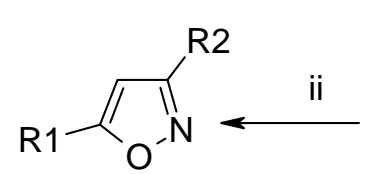

$3 a, 41 \%$

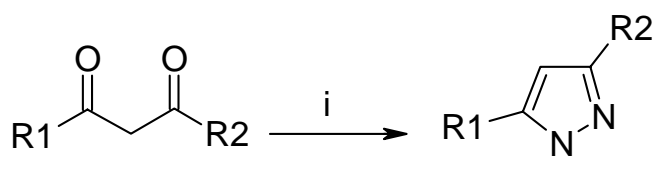

1a-1e

2a-2e, $51-95 \%$

\section{Scheme 1}

The presence of hydrogen bond donors (N-H groups in a pyrazole ring) and hydrogen bond acceptors (pyridine nitrogens) might result in intermolecular contact within the crystal structures of the products. Indeed, X-ray structural study of $2 \mathbf{c}^{10}{ }^{10}$ revealed the existence of hydrogenbonded dimers, which stack along the crystallographic axis, whereas for the compound 2a infinite head-to-tail chains were found. ${ }^{11}$

Azachalcones look like the obvious precursors for the synthesis of unsym-isoxazole. Recently, we found that the synthesis of azachalcones, starting from acetylpyridines and pyridinecarbaldehydes, is more complicated than it was thought before. ${ }^{12}$ For this reason in the present work, unsym-isoxazoles were not studied.

For the access to 1,3-diazole and triazole subsystems, one can start from cheap and available cyanopyridine using nucleophilic addition reactions. The cyanopyridine could be easily acylated or alkylated by appropriate pyridine derivatives and the intermediates obtained could then be introduced into the next steps of the heterocycle synthesis (Scheme 2). 


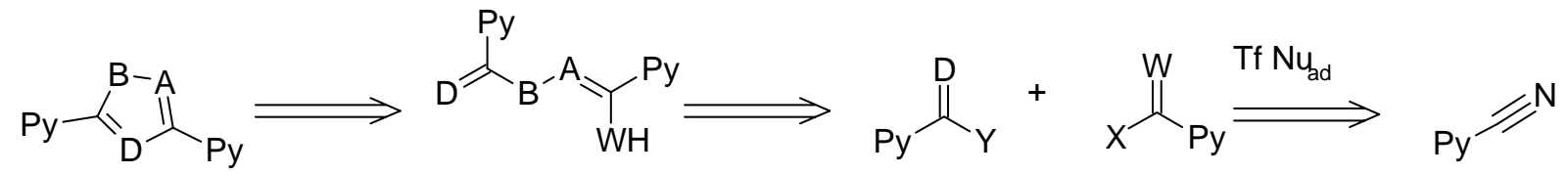

$\mathrm{A}-\mathrm{B}=\mathrm{N}-\mathrm{NH}, \mathrm{N}-\mathrm{O}, \mathrm{CH}-\mathrm{N}, \mathrm{CH}-\mathrm{S}$;

$\mathrm{D}=\mathrm{NH} / \mathrm{N}^{*}, \mathrm{NAr}, \mathrm{O}$;

$\mathrm{W}=\mathrm{NH}, \mathrm{O}$;

$X=\mathrm{NHNH} 2, \mathrm{NH} 2 \mathrm{OH}, \mathrm{CH} 2 \mathrm{NH} 2, \mathrm{CH} 2 \mathrm{Br}$;

$\mathrm{Y}=\mathrm{Hal}, \mathrm{OMe}, \mathrm{SH}$.

*depends on "B" nature

\section{Scheme 2}

In the synthesis of the isomers of dipyridylimidazole, the key-substance is 2-pyridyl-2aminoethanone 6 - the ambiphilic precursor for cyclocondensation (Scheme 3). In spite of the published results, ${ }^{13,14,15,16}$ there were some uncertainties about the influence of the electronic and spatial factors of the substrate on the course of the reaction. We found that the yield of the tosylation step (preparation of compounds 5 - see Scheme 3) is more influenced by the configuration of the oxime than by the electronic factors. The next step - the Neber rearrangement - was found to be dependent neither on the electronic nature of the hetaryl substituent nor on the spatial factor. The isolation of the diketal derivative of the aminoketone might result in an increasing yield. ${ }^{14}$ The key-step of the reaction, shown in Scheme 3, is based on the reaction of methyl carbimidate 8, generated in situ from the appropriate nitrile 7 and aminoketone $\mathbf{6 b} .^{17}$ The target imidazoles 9a-9d were isolated in moderate to good yields. The main drawback of this method is the formation of the diarylpyrazine, which is the product of autocondensation of $\mathbf{6} .^{13}$

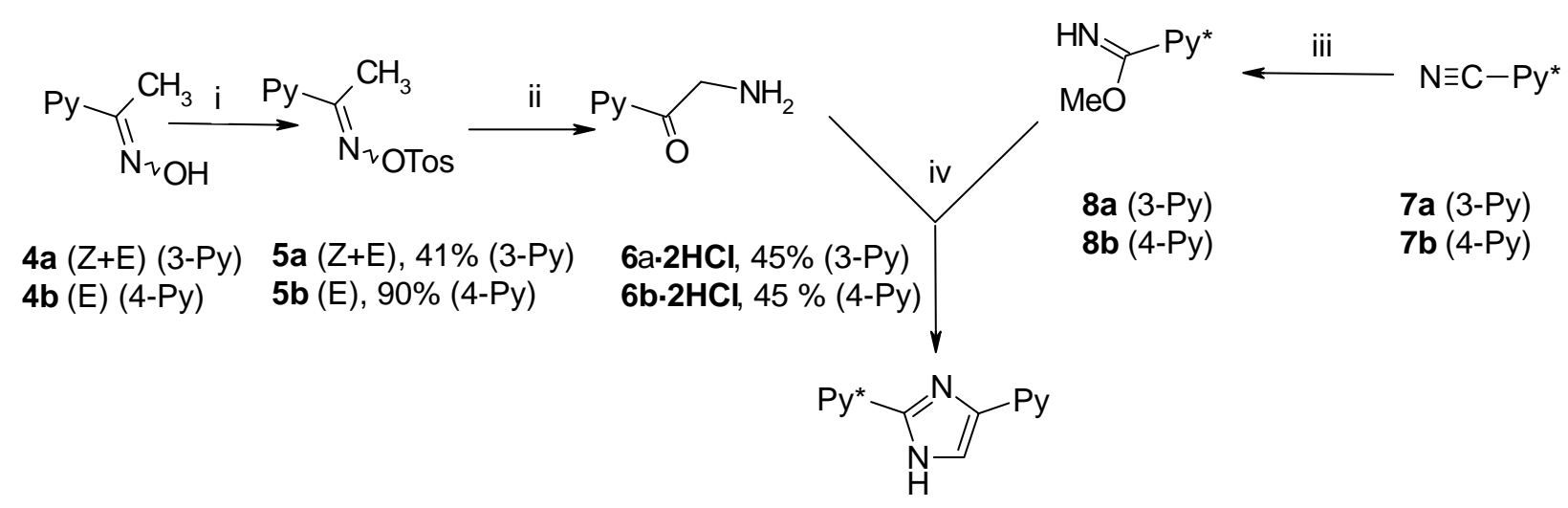

9a-9d, 38-70\%

i - TsCl, pyridine, $0{ }^{\circ} \mathrm{C}$; $\mathrm{ii}-\mathrm{KOEt}$, rt, $1 \mathrm{~h}, \mathrm{HCl}$; iii - $\mathrm{MeONa}, \mathrm{MeOH}$, rt; iv - AcOH, reflux, $2 \mathrm{~h}$

\section{Scheme 3}


In order to obtain thiazolylpyridines (Scheme 4), we used the S-alkylation of thioamide $\mathbf{1 1}$ by easy-available ${ }^{18} \omega$-bromoketone 10. Thioamide is also obtained using a literature procedure, which includes catalytic hydrogen sulfide addition to nitrile $7 .^{19} \mathrm{We}$ improved the known technique $^{20}$ in such a way, that the initially formed insoluble thiouronium salt is separated, and then coverted into the thiazole by quenching with triethylamine. In spite of low and moderate yields of 12, the total outcome for the thiazolylpyridine derivatives was significantly raised as compared to the work cited above.

Our synthetic approach to the oxazole analogue of $\mathbf{1 2}$ was based on the preparation of the acyclic intermediate 13. Unfortunately, the latter was unable to form the 5-membered ring under several different dehydrating conditions (Scheme 5). Finally, the oxazole 14 was the minor product along with the starting material.

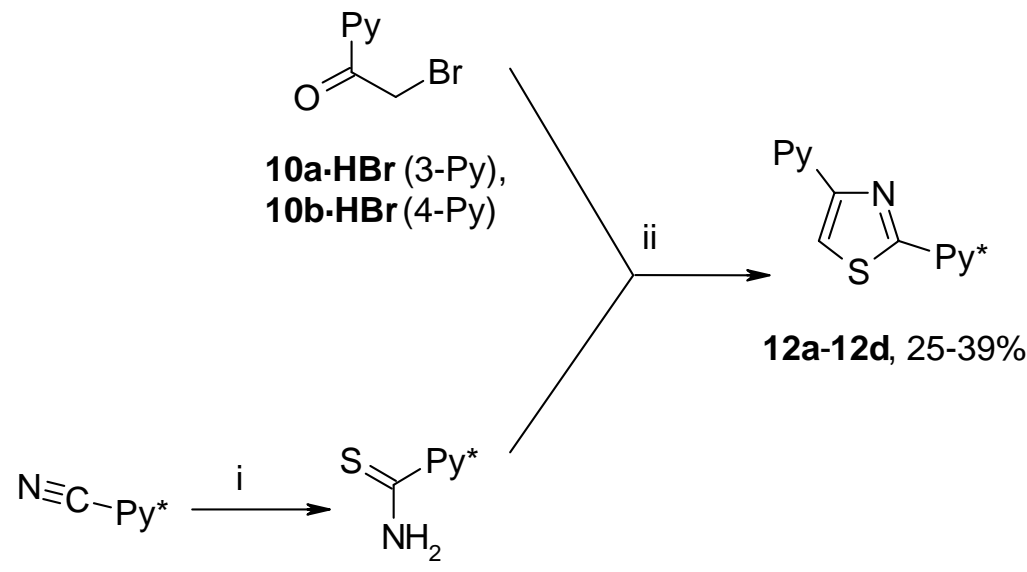

7a (3-Py), $\quad 11 a$ (3-Py),

7b (4-Py) 11b (4-Py)

$\mathrm{i}-\mathrm{Na}_{2} \mathrm{~S}, \mathrm{H}_{2} \mathrm{~S}$, benzene- $\mathrm{H}_{2} \mathrm{O},(\mathrm{Cet}) \mathrm{Me}_{3} \mathrm{~N}^{+} \mathrm{Br}$; ii - ${ }^{-} \mathrm{Et}_{3} \mathrm{~N}, \mathrm{EtOH}$, reflux.

\section{Scheme 4}

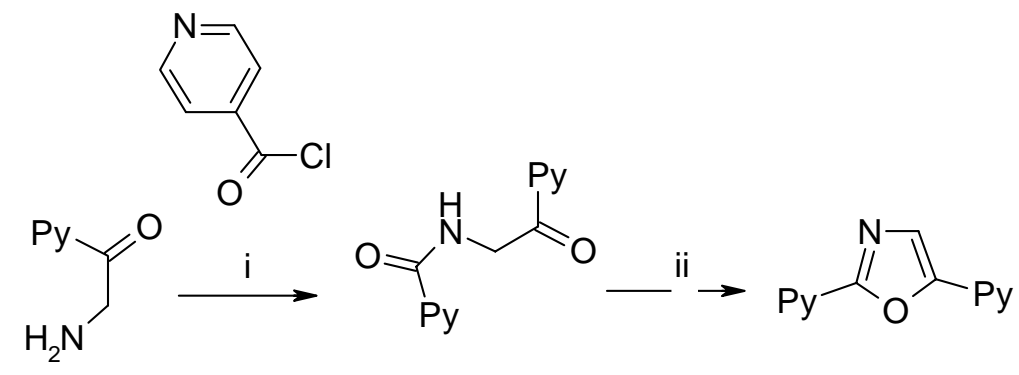
$6 b \cdot 2 \mathrm{HCl}$
13 (4-Py), 52\%
14 (4-Py), 6\%

i - DMF, heat; ii - $170{ }^{\circ} \mathrm{C}$.

\section{Scheme 5}


Concerning the azole systems with three heteroatoms, particular attention was paid to the compounds with an oxadiazole ring. In the case of the 1,2,4-oxadiazole subsystem, no significant complications were found. We were lucky to obtain the target 3,5-dipyridyl-derivatives 18 in two steps with high yields (Scheme 6). Starting from commercially available pyridoyl chlorides 15 and available amidoximes 16, O-pyridoylamidoximes $\mathbf{1 7}$ were synthesized. ${ }^{21,22}$ These intermediates were then converted into oxadiazole by removal of water by heating.

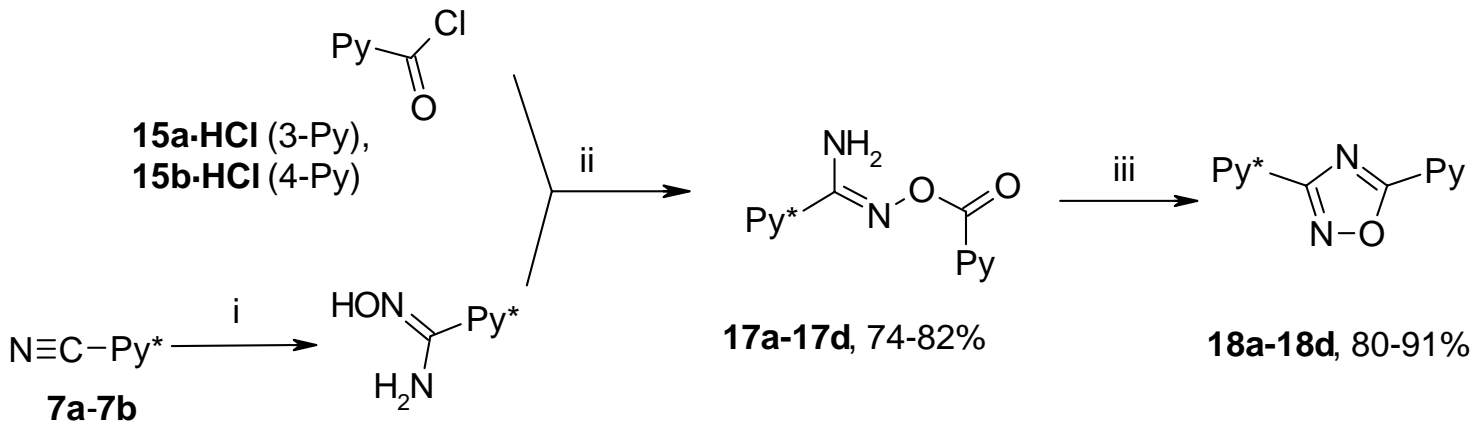

16a (3-Py),

16b (4-Py)

$\mathrm{i}-\mathrm{NH}_{2} \mathrm{OH}$, EtOH, reflux; $\mathrm{ii}-\mathrm{K}_{2} \mathrm{CO}_{3}$, acetone; iii - toluene, reflux.

\section{Scheme 6}

Although pyridine-containing 1,3,4-oxadiazoles were already mentioned in the literature, ${ }^{23,24}$ we adopted a novel method ${ }^{25}$ for their preparation via a dipolar intermediate (Scheme 7). In this case 5-pyridyl-tetrazole $\mathbf{1 9}$ could be regarded as the nucleophilic adduct of the azide-anion and the appropriate nitrile. The nature of the substituent at $\mathrm{C}^{5}$ influenced the product yield to a negligible extent. We also conducted this reaction under microwave irradiation and found that yields were higher and shorter reaction times were required.

The 4-aryl substituted triazole 23 was obtained in the same manner in three steps, starting from 4-bromoaniline and tetrazole 19b (Scheme 8). In this case, the reaction mixture was contaminated with several side-products that were not identified.

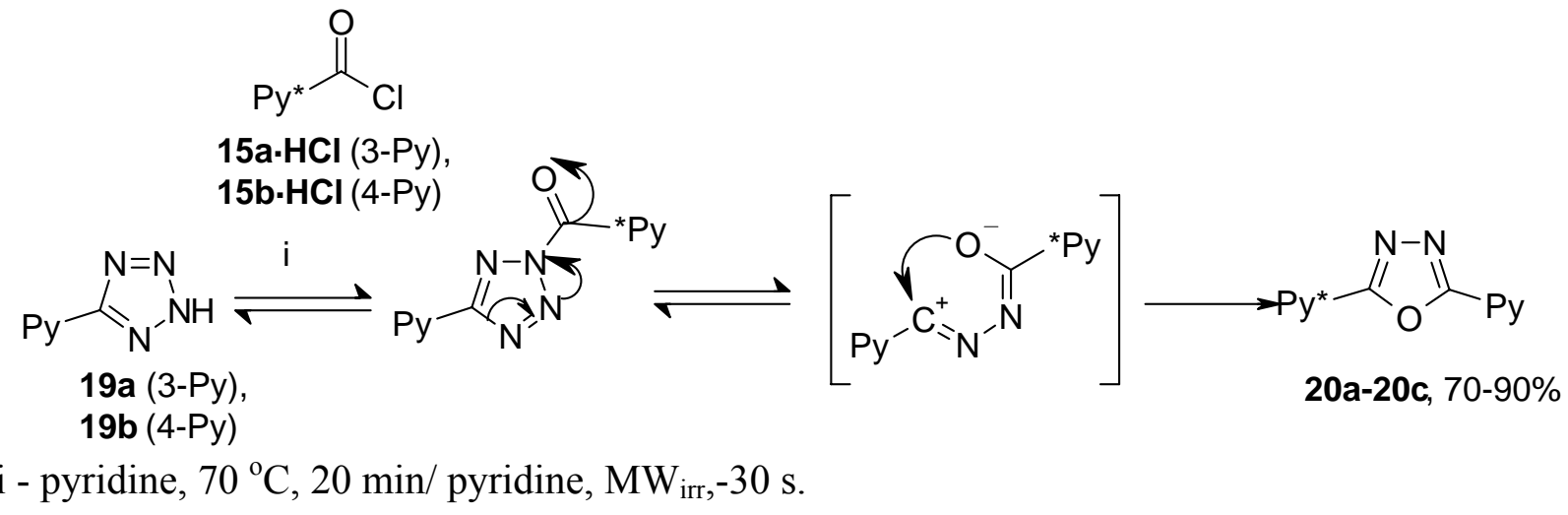

Scheme 7 


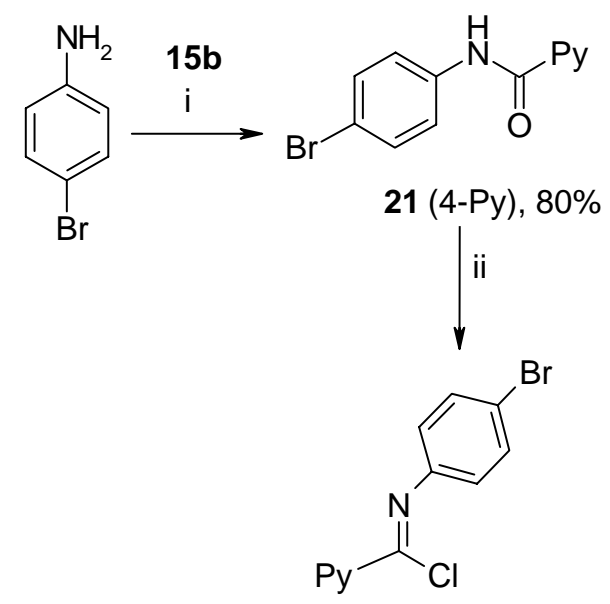

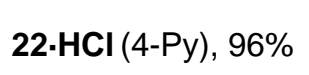

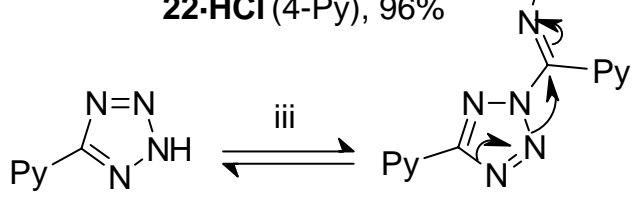
$19 b$ (4-Py)

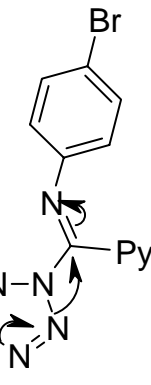<smiles>C=CCCC(Br)=NN=C(P)[C+](C)c1ccc(Br)cc1</smiles>

$\mathrm{i}$ - DMF, heat; $\mathrm{ii}-\mathrm{PCl}_{5}$ reflux; iii - pyridine, $60{ }^{\circ} \mathrm{C}, 20 \mathrm{~min}$

\section{Scheme 8}

It should be emphasized, that in all cases of such rearrangements, no products of further transformation of $\mathrm{N}^{1}$-acyl derivatives, such as 1,2,4-oxadiazole or unsym-triazole, were detected (Scheme 9).

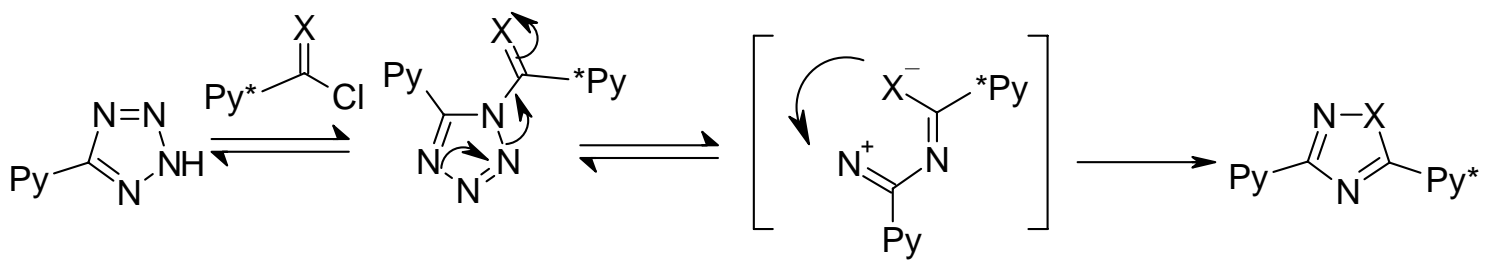

\section{Scheme 9}

We also tested tetrazolyl-pyridines in the solvent-dependent reactions. It is known, ${ }^{26}$ that $(Z)$ and $(E)-\mathrm{N}^{2}$-imidoyltetrazoles are labile, and can reversibly interconvert into each other. In our case (Scheme 10) in aprotic and less-polar toluene, the $Z$-form dominates and in the intermediate (shown in brackets), the cationic center attacks the electron-riched naphthalene ring resulting in the condensed 2,5-di(4-pyridyl)-3H-naphtho[1,2-e]-1,3,4-triazepine 26b. Alternatively, triazole 26a was registered as a trace by TLC control. 
<smiles>Nc1cccc2ccccc12</smiles>

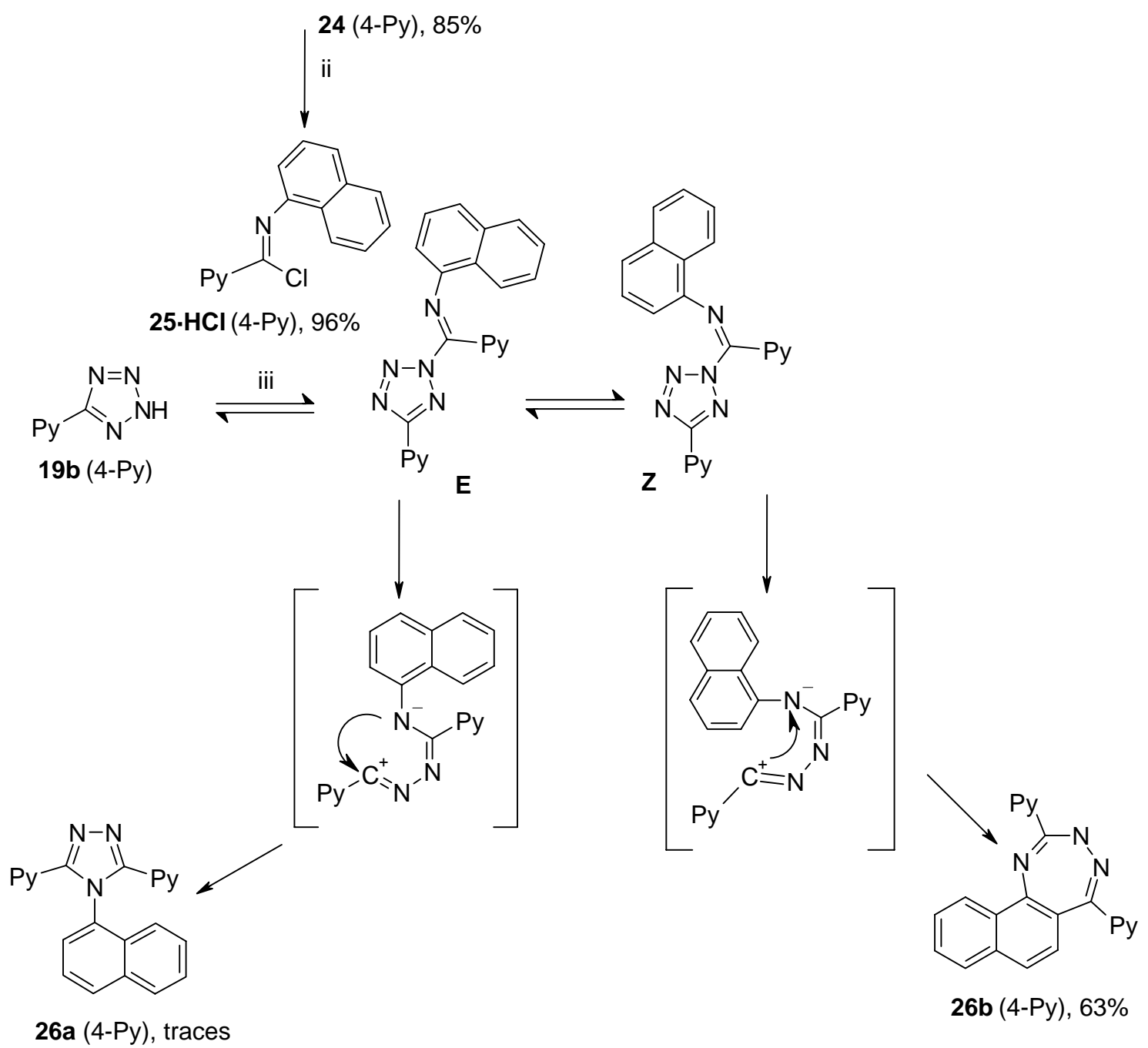

26a (4-Py), traces

i - DMF, heat; ii - $\mathrm{PCl}_{5}$ reflux; iii $-\mathrm{CH}_{2} \mathrm{Cl}_{2}-\mathrm{H}_{2} \mathrm{O}, \mathrm{NaOH}, \mathrm{Et}_{3} \mathrm{~N}$; TEBAC; MePh, reflux.

\section{Scheme 10}

For the synthesis of unsym-triazoles 29, we applied the procedure depicted in Scheme 11. This approach is based on the preparation and isolation of the unsymmetrical amidrazones 28 with their consequent dehydration by heating. 
$\mathrm{PyCONHNH}_{2}$

27a (3-Py),

27b (4-Py)

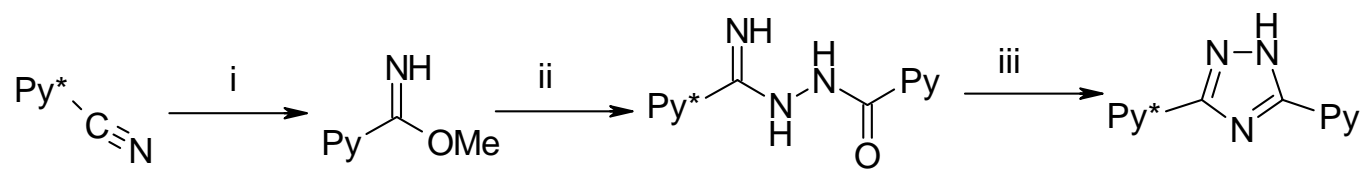

$\begin{array}{lll}\mathbf{7 a - 7 b} & \mathbf{8 a}(3-P y), & \mathbf{2 8 a - 2 8 d}, 75-92 \%\end{array}$

i - MeONa, MeOH, rt; ii - MeOH, heat; $180^{\circ} \mathrm{C}$ vacuum.

\section{Scheme 11}

In summary, by the design of the reaction partners, we have developed a convenient and conceptually simple synthethic pathway to a family of novel azole bearing pyridines which are promising ligands for coordination chemistry.

\section{Experimental Section}

General Procedures. All starting materials were obtained commercially, unless otherwise stated, (Aldrich, Lancaster or Acros Organics) and all solvents were dried using literature procedures. TLC was performed using aluminium plates precoated with silica $60 \mathrm{~F}_{254}$ (Merck) and visualized by iodine or UV light $(254 \mathrm{~nm})$. Column chromatography was carried out on silica gel (Fluka, particle size $0.040-0.063 \mathrm{~nm}$ ). The IR-spectra were recorded (nujole) on a Specord $75 \mathrm{IR}$ instrument. NMR spectra were recorded in $\mathrm{CDCl}_{3}$, unless otherwise stated, on a Varian VXR 400S NMR spectrometer with tetramethylsilane as an internal standard. Mass spectra were recorded on a Jeol ${ }^{\circ}$ "MS-D300" Spectrometer (EI, $70 \mathrm{eV}$ ), coupled with a Hewlett Packard 5890 series II gas chromatograph using a 25m HP1 (methyl-silicone) column. Elemental analyses data were obtained on a Carlo-Erba ${ }^{\circledR}$ ER-20 elemental analyzer. Melting points and boiling points were recorded at atmospheric pressure, unless otherwise stated, and are uncorrected.

\section{Typical procedure for the preparation of 3,5-diaryl-1H-pyrazoles}

Hydrazine hydrate $(15 \mathrm{mmol})$ in $\mathrm{MeOH}(20 \mathrm{ml})$ was added to a solution of the appropriate $\beta$ diketone $^{9,27}$ (10 mmol). The resulting mixture was stirred and refluxed for $2 \mathrm{~h}$, and was then cooled and evaporated. The residue was crystallized from 2-propanol. The yields, melting points and spectral data of 2a-2c are presented in Tables 1,2. 
Table 1. Yields and spectral data of 3,5-diaryl-1H-pyrazoles 2a-2e

yield,
$\%$ $\begin{gathered}\begin{array}{c}\text { m.p.(lit.) } \\ { }^{\circ} \mathrm{C}\end{array} \\ \begin{array}{c}\mathrm{IR} \\ \left(\mathrm{v}, \mathrm{cm}^{-1}\right)\end{array}\end{gathered}$

Table 2. ${ }^{13} \mathrm{C}$ NMR $\left(\mathrm{CDCl}_{3}, \delta\right.$ ppm) data of 3,5-diaryl-1H-pyrazoles 2a-2c. Structure-chemical shift correlations are available from the literature ${ }^{28,29,30}$

\begin{tabular}{lccccccc}
\hline & $\operatorname{Py}\left(\mathrm{C}^{2} / \mathrm{C}^{2}\right)^{*}$ & $\mathrm{Py}\left(\mathrm{C}^{3} / \mathrm{C}^{3}\right)$ & $\mathrm{Py}\left(\mathrm{C}^{4} / \mathrm{C}^{4^{3}}\right)$ & $\mathrm{Py}\left(\mathrm{C}^{5} / \mathrm{C}^{5^{3}}\right)$ & $\operatorname{Py}\left(\mathrm{C}^{6} / \mathrm{C}^{6}\right)$ & $\begin{array}{c}\text { Pyraz } \\
\left(\mathrm{C}^{3} / \mathrm{C}^{5}\right)\end{array}$ & $\begin{array}{c}\text { Pyraz } \\
\left(\mathrm{C}^{4}\right)\end{array}$ \\
\hline $\mathbf{3 1}$ & 150.2 & 122.3 & - & 122.3 & 150.2 & 148.4 & 110.5 \\
$\mathbf{3 2}$ & 150.5 & - & 135.9 & 124.1 & 150.9 & 147.6 & 108.2 \\
$\mathbf{3 3}$ & $150.2 /-$ & $122.5 / 121.2$ & -1136.9 & $122.5 / 123.1$ & $150.2 / 151.5$ & $148.9 / 148.6$ & 113.2 \\
\hline
\end{tabular}

* the atoms of pyridine rings with lower locant number (2-pyridyl) were marked by apostrophes.

3-Phenyl-5-(2-pyridyl)-1H-pyrazole (2d). Yield 84\%, colorless prismatic crystals. ${ }^{1} \mathrm{H}$ NMR $\left(\mathrm{CDCl}_{3}, \delta, \mathrm{ppm}, J, \mathrm{~Hz}\right): 8.70$ (dd, $\left.1 \mathrm{H}, 6 \mathrm{H}-\mathrm{Py},{ }^{3} \mathrm{~J}=4.5,{ }^{4} \mathrm{~J}=1.8\right), 7.90-7.88(\mathrm{~m}, 2 \mathrm{H}, 2,6-\mathrm{H}-\mathrm{Ph}), 7.80$ (dd, 1H, 3H-Py, $\left.{ }^{3} \mathrm{~J}=7.7,{ }^{4} \mathrm{~J}=1.8\right), 7.75\left(\mathrm{dt}, 1 \mathrm{H}, 4 \mathrm{H}-\mathrm{Py},{ }^{3} \mathrm{~J}=7.7,{ }^{4} \mathrm{~J}=1.8\right), 7.64-7.61(\mathrm{~m}, 1 \mathrm{H}, 4 \mathrm{H}-\mathrm{Ph})$, 7.40 (dd, 1H, 5H-Py, $\left.{ }^{3} \mathrm{~J}=4.5,{ }^{3} \mathrm{~J}=7.7\right), 7.26-7.22$ (m, 2H, 3,5-H-Ph), 7.12 (c, $\left.1 \mathrm{H}, 4 \mathrm{H}-\mathrm{Pyraz}\right) .{ }^{13} \mathrm{C}$ NMR $\left(\mathrm{CDCl}_{3}, \delta, \mathrm{ppm}\right.$ ): 151.3, 149.5, 148.8, 148.1, 137.2, 132.1, 129.0, 128.2, 125.4, 122.2, 121.3, 100.2. Anal. Calcd. for $\mathrm{C}_{14} \mathrm{H}_{11} \mathrm{~N}_{3}$ : C, 76.00; H, 5.01; N, 18.99. Found: C, 76.20; H, 4.92; $\mathrm{N}, 19.02$.

3-(2-Thienyl)-5-(2-pyridyl)-1H-pyrazole (2e). Yield 77\%, yellow solid. ${ }^{1} \mathrm{H}$ NMR $\left(\mathrm{CDCl}_{3}, \delta\right.$, ppm, $J, \mathrm{~Hz}): 8.64$ (d, 1H, 6H-Py, $\left.{ }^{3} \mathrm{~J}=4.5\right), 8.08\left(\mathrm{~d}, 1 \mathrm{H}, 3 \mathrm{H}-\mathrm{Py},{ }^{3} \mathrm{~J}=7.0\right), 7.83$ (d, 1H, 3H-Tf, $\left.{ }^{3} \mathrm{~J}=4.0\right), 7.72\left(\mathrm{dt}, 1 \mathrm{H}, 4 \mathrm{H}-\mathrm{Py},{ }^{3} \mathrm{~J}=7.0,{ }^{4} \mathrm{~J}=1.4\right), 7.60\left(\mathrm{~d}, 1 \mathrm{H}, 5 \mathrm{H}-\mathrm{Tf},{ }^{3} \mathrm{~J}=5.0\right), 7.37(\mathrm{dd}, 1 \mathrm{H}, 5-\mathrm{HPy}$, $\left.{ }^{3} \mathrm{~J}=7.0,{ }^{3} \mathrm{~J}=4.5\right), 7.18$ (dd, $\left.1 \mathrm{H}, 4-\mathrm{HTf},{ }^{3} \mathrm{~J}=5.0,{ }^{3} \mathrm{~J}=4.0\right), 6.95$ (c, $\left.1 \mathrm{H}, 4 \mathrm{H}-\mathrm{Pyraz}\right) .{ }^{13} \mathrm{C}$ NMR $\left(\mathrm{CDCl}_{3}\right.$, 
$\delta$, ppm,): 151.0, 148.8, 143.4, 142.8, 140.6, 137.0, 135.1, 133.1, 124.2, 123.6, 121.1, 100.0. Anal. Calcd. for $\mathrm{C}_{12} \mathrm{H}_{9} \mathrm{~N}_{3} \mathrm{~S}$ : C, 63.41; H, 3.99; N, 18.49. Found: C, 62.95; H, 3.73; N, 18.80 .

3,5-Di(3-pyridyl)isoxazole (3a). An ethanol solution of 1,3-di(3-pyridyl)-1,3-propandione (1b) $(2.22 \mathrm{~g}, 10 \mathrm{mmol})$ was added to hydroxylamine $(15 \mathrm{mmol})$ in ethanol. The mixture was stirred at $80{ }^{\circ} \mathrm{C}$ for $12 \mathrm{~h}$, and was then cooled and evaporated. The residue was carefully extracted by dichloromethane (DCM, 3×20 ml), the organic phase was dried (sodium sulfate), and evaporated. The residue was crystallized from ethanol to yield $900 \mathrm{mg}(41 \%)$ of oxazole 3a, m.p. $202{ }^{\circ} \mathrm{C}$, lit. $198{ }^{\circ} \mathrm{C} .{ }^{9}{ }^{13} \mathrm{C} \mathrm{NMR}\left(\mathrm{CDCl}_{3}, \delta, \mathrm{ppm},\right): 164.2,151.0,150.8,150.6,150.5,146.4,136.2,135.9$, $124.9,124.5,97.4$.

(E/Z)-Tosylates of 3-acetylpyridine oxime (5a). (E/Z)-3-Acetylpyridine oxime (4a) (10.3 g, $75 \mathrm{mmol}$ ) was dissolved in $36 \mathrm{ml}$ of anhydrous pyridine, and the resulting mixture was icecooled. The reaction mixture was quenched by $15.7 \mathrm{~g}(82 \mathrm{mmol})$ of tosylchloride $(\mathrm{TsCl})$ with vigorous stirring to keep the temperature below $5{ }^{\circ} \mathrm{C}$. The mixture was kept overnight at $0{ }^{\circ} \mathrm{C}$, and then poured onto $400 \mathrm{~g}$ of crushed ice. After slow crystallization of the initially formed yellow oil, the product was filtered, and crystallized from aqueous alcohol to give $9.9 \mathrm{~g}(41 \%)$ of beige crystals, m.p. $77-79{ }^{\circ} \mathrm{C}$, lit. $78{ }^{\circ} \mathrm{C}$. ${ }^{13}$ The ratio $(3: 2)$ of E- and Z-isomers of 5a was determined by ${ }^{1} \mathrm{H}$ NMR. ${ }^{1} \mathrm{H}$ NMR Z-5a $\left(\mathrm{CDCl}_{3}, \delta\right.$, ppm, $\left.J, \mathrm{~Hz}\right): 2.38$ (s, 3H, CH -Ts), 2.42 (s, $3 \mathrm{H}, \mathrm{CH}_{3}-\mathrm{C}=\mathrm{NOTs}$ ), 7.36 (d, 2H, 3,5-H-Ts, ${ }^{3} \mathrm{~J}=7.6$ ), 7.42 (ddd, $\left.1 \mathrm{H}, 5 \mathrm{H}-\mathrm{Py},{ }^{3} \mathrm{~J}=4.7,{ }^{4} \mathrm{~J}=1.8\right), 7.78$ (dt, 1H, 4H-Py, $\left.{ }^{3} \mathrm{~J}=4.7,{ }^{4} \mathrm{~J}=1.8\right), 7.86$ (d, 2H, 2,6-H-Ts, $\left.{ }^{3} \mathrm{~J}=7.6\right), 8.60$ (dd, 1H, 6H-Py, ${ }^{3} \mathrm{~J}=4.9$, $\left.{ }^{4} \mathrm{~J}=1.8\right), 8.68\left(\mathrm{~d}, 1 \mathrm{H}, 2 \mathrm{H}-\mathrm{Py},{ }^{4} \mathrm{~J}=1.8\right) .{ }^{1} \mathrm{H} \mathrm{NMR} E 5 \mathrm{a}\left(\mathrm{CDCl}_{3}, \delta\right.$, ppm, J, Hz): 2.37 (c, 3H, CH3Ts), 2.51 (c, 3H, CH3-C=NOTs), 7.34 (ddd, 1H, 5H-Py, $\left.{ }^{3} \mathrm{~J}=4.7,{ }^{4} \mathrm{~J}=1.8\right), 7.39$ (d, 2H, 3,5-H-Ts, $\left.{ }^{3} \mathrm{~J}=7.5\right), 7.90\left(\mathrm{dt}, 1 \mathrm{H}, 4 \mathrm{H}-\mathrm{Py},{ }^{3} \mathrm{~J}=4.7,{ }^{4} \mathrm{~J}=1.8\right), 7.94\left(\mathrm{~d}, 2 \mathrm{H}, 2,6-\mathrm{H}-\mathrm{Ts},{ }^{3} \mathrm{~J}=7.5\right), 8.65(\mathrm{dd}, 1 \mathrm{H}, 6 \mathrm{H}-$ Py, $\left.{ }^{3} \mathrm{~J}=4.9,{ }^{4} \mathrm{~J}=1.8\right), 8.82$ (d, $\left.1 \mathrm{H}, 2 \mathrm{H}-\mathrm{Py},{ }^{4} \mathrm{~J}=1.8\right)$.

(E)-Tosylate of 4-acetylpyridine oxime (5b). In a similar manner from $8.20 \mathrm{~g}$ (60 mmol) of (E)-4-acetylpyridine oxime $\mathbf{4 b}$ and $12.4 \mathrm{~g}(65 \mathrm{mmol})$ of $\mathrm{TsCl} 15.65 \mathrm{~g}(90 \%)$ of $5 \mathbf{b}$ was obtained, m.p. $81{ }^{\circ} \mathrm{C}$, lit. $81{ }^{\circ} \mathrm{C}{ }^{4} .1 \mathrm{H}$ NMR $\left(\mathrm{CDCl}_{3}, \delta\right.$, ppm, $J, \mathrm{~Hz}$ ): 2.38 (s, 3H, CH3-Ts), 2.53 (s, 3H, $\mathrm{CH} 3-\mathrm{C}=\mathrm{NOTs}), 7.40\left(\mathrm{~d}, 2 \mathrm{H}, 3,5-\mathrm{H}-\mathrm{Ts},{ }^{3} \mathrm{~J}=7.5\right), 7.95\left(\mathrm{~d}, 2 \mathrm{H}, 2,6-\mathrm{H}-\mathrm{Ts},{ }^{3} \mathrm{~J}=7.5\right), 8.08(\mathrm{~d}, 2 \mathrm{H}$, 3,5H-Py, $\left.{ }^{3} \mathrm{~J}=6.7\right), 9.02$ (d, 2H, 2,6-H-Py, ${ }^{4} \mathrm{~J}=6.7$ ).

2-Amino-1-(3-pyridyl)ethanone (6a). The reaction was carried out under an argon atmosphere. Potassium (1.5 g, $38 \mathrm{mmol}$ ) was cautiously dissolved in $25 \mathrm{ml}$ of dry ether. (E/Z)-Tosylates of 3acetylpyridine oxime $5 \mathbf{a}(9.9 \mathrm{~g}, 34 \mathrm{mmol})$ was then added to this solution. The resulting mixture was stirred at room temperature for $1 \mathrm{~h}$. The resulting red-colored solution was filtered from sodium tosylate, and quenched by $600 \mathrm{ml}$ of dry ether. The sodium tosylate formed once again was filtered. The product was collected after ethereal phase extraction $(3 \times 25 \mathrm{ml} 2 \mathrm{~N} \mathrm{HCl})$, followed by evaporation of the water phase (temperature should not exceed $40{ }^{\circ} \mathrm{C}$ ). Crystallization from absolute alcohol gave $3.2 \mathrm{~g} \mathrm{(45 \% )}$ of white crystals of the dihydrochloride, m.p. $172{ }^{\circ} \mathrm{C}$ (dec.), lit. $172{ }^{\circ} \mathrm{C}(\mathrm{dec}) .{ }^{13}$ This compound was sensitive to moisture and air. ${ }^{1} \mathrm{H}$ NMR $\left(\mathrm{CDCl}_{3}, \delta, \mathrm{ppm}, \mathrm{J}, \mathrm{Hz}\right): 3.55$ (m, 2H, $\left.\mathrm{CH}_{2}-\mathrm{NH}_{3}{ }^{+}\right), 6.58$ (br.t, $\left.3 \mathrm{H}, \mathrm{NH}_{3}{ }^{+}\right), 7.48$ (m, 1H, 5HPy), 8.05 (d, 1H, 4H-Py, $\left.{ }^{3} \mathrm{~J}=7.5\right), 8.71$ (d, 1H, 6H-Py, $\left.{ }^{3} \mathrm{~J}=4.8\right), 9.12$ (s, 1H, 2H-Py), 11.21 (br.s, 1H, $\mathrm{NH}^{+}$-Py). IR: $3450\left(\mathrm{NH}, \mathrm{NH}_{3}\right) ; 1690(\mathrm{C}=\mathrm{O})$. 
2-Amino-1-(4-pyridyl)ethanone (6b). In a similar manner from $14.5 \mathrm{~g}(50 \mathrm{mmol})$ of $\mathbf{5 b}$ and $2.15 \mathrm{~g}$ (55 mmol) of potassium $\mathbf{6 b}$ was obtained as colorless needles. Yield 4.72g (45\%), m.p. 192-228 ${ }^{\circ} \mathrm{C}$ (dec.), lit. $230-235^{\circ} \mathrm{C}$ (dec.). ${ }^{31}{ }^{1} \mathrm{H} \mathrm{NMR}\left(\mathrm{CDCl}_{3}, \delta\right.$, ppm, J, Hz): 3.55 (m, 2H, $\mathrm{CH}_{2}-$ $\mathrm{NH}_{3}{ }^{+}$), 6.65 (br.T, 3H, NH3 ${ }^{+}$), 7.42 (d, 2H, 3,5-H-Py, $\left.{ }^{3} \mathrm{~J}=5.0\right), 8.60$ (d, 2H, 2,6H-Py, ${ }^{3} \mathrm{~J}=5.0$ ), 11.05 (brs, 1H, $\mathrm{NH}^{+}$-Py). IR: $3450\left(\mathrm{NH}, \mathrm{NH}_{3}\right) ; 1690(\mathrm{C}=\mathrm{O})$.

\section{Typical procedure for the preparation of 2,4-dipyridyl-1H-imidazoles 9a-9d}

The methanol solution $(25 \mathrm{ml}, 0.5 \mathrm{M})$ of appropriate methyl pyridylcarbimidate ${ }^{7}$ was quenched by acetic acid up to a neutral $\mathrm{pH}$. To this mixture, 2-amino-1-pyridylethanone dihydrochloride (2.6 g, $12.5 \mathrm{mmol}$ ) was added. The resulting mixture was stirred for $1 \mathrm{~h}$, and then refluxed for $2 \mathrm{~h}$. Then it was cooled, and evaporated to dryness. The residue was dissolved in a $10 \%$ sodium hydroxide solution so that the $\mathrm{pH}$ stayed near 10 , and this solution was extracted by DCM $(3 \times 10 \mathrm{ml})$. The organic phase was dried and evaporated, the residue was then crystallized from chloroform and acetone (to remove ammonia chloride). The yields, melting points and spectral data of 9a-9d are presented in Tables 3,4.

Table 3. Yields and spectral data of 2,4-dipyridyl-1 $H$-imidazoles 9a-9d

\begin{tabular}{|c|c|c|c|c|c|c|c|c|}
\hline & \multirow{2}{*}{$\begin{array}{c}\text { Starting } \\
\text { materials }\end{array}$} & \multirow[t]{2}{*}{ Color } & \multirow[t]{2}{*}{ Yield, \% } & \multirow{2}{*}{${ }^{\mathrm{m} . \mathrm{p} .}$} & \multirow[t]{2}{*}{$\operatorname{IR}\left(v, \mathrm{~cm}^{-1}\right):$} & \multicolumn{3}{|c|}{$\begin{array}{c}\text { Found: } \\
\text { Anal. Calcd. for } \\
\mathrm{C}_{13} \mathrm{H}_{10} \mathrm{~N}_{4}\end{array}$} \\
\hline & & & & & & $\begin{array}{c}\mathrm{C} \\
70.25\end{array}$ & $\begin{array}{c}\mathrm{H} \\
4.54 \\
\end{array}$ & $\begin{array}{c}\mathrm{N} \\
25.21\end{array}$ \\
\hline $9 a$ & $6 a+8 a$ & light-yellow & 38 & 169 & $3300(\mathrm{NH})$ & 69.82 & 4.12 & 25.39 \\
\hline $9 b$ & $6 a+8 b$ & light-yellow & 56 & 183 & $3300(\mathrm{NH})$ & 69.75 & 4.01 & 25.74 \\
\hline 9c & $6 b+8 a$ & colorless & 54 & 192 & $3300(\mathrm{NH})$ & 69.87 & 4.53 & 25.11 \\
\hline 9d & $6 b+8 b$ & colorless & 70 & 209 & $3300(\mathrm{NH})$ & 70.12 & 4.38 & 24.98 \\
\hline
\end{tabular}

Table 4. ${ }^{1} \mathrm{H} \mathrm{NMR}\left(\mathrm{CDCl}_{3}, \delta \mathrm{ppm}, \mathrm{J} \mathrm{Hz}\right),{ }^{13} \mathrm{C} \mathrm{NMR}\left(\mathrm{CDCl}_{3}, \delta \mathrm{ppm}\right)$ data of 2,4-dipyridyl-1Himidazoles 9a-9d Structure -chemical shift correlations were reported in the literature. ${ }^{32}$ See supporting info. Page 241

Typical procedure for the preparation of 2,4-dipyridylthiazoles $12 a-12 d^{33}$

2-Bromo-1-pyridinylethanone (10a or 10b) (2.81 g, $10 \mathrm{mmol})$, pyridylcarbothioamide (11a or 11b) $(1.38 \mathrm{~g}, 10 \mathrm{mmol})$ and $50 \mathrm{ml}$ of absolute ethanol were mixed in a $100 \mathrm{ml}$ round-bottom flask. The resulting mixture was refluxed for $2 \mathrm{~h}$, then cooled and filtered. Triethylamine $(2.5 \mathrm{ml}$, $20 \mathrm{mmol})$ ) and isopropanol $(30 \mathrm{ml})$ were added to the resulting solid, and the reaction mixture 
was brought to reflux for $30 \mathrm{~min}$. After cooling and evaporation, the residue was quenched with $10 \mathrm{ml}$ of water and was extracted by DCM $(3 \times 30 \mathrm{ml})$. The organic phase was dried, evaporated and the rest was crystallized from 2-propanol to give the appropriate thiazoles. The yields, melting points and spectral data of 12a-12d are presented in Tables 5,6.

Table 5. Yields and spectral data of 2,4-dipyridylthiazoles 12a-12d

\begin{tabular}{|c|c|c|c|c|c|c|c|}
\hline & \multirow{2}{*}{$\begin{array}{c}\text { Starting } \\
\text { materials }\end{array}$} & \multirow[t]{2}{*}{ Color } & \multirow[t]{2}{*}{ Yield, \% } & \multirow{2}{*}{$\begin{array}{c}\text { m.p. } \\
{ }^{\circ} \mathrm{C}\end{array}$} & \multicolumn{3}{|c|}{$\begin{array}{c}\text { Found: } \\
\text { Anal. Calcd. for } \\
\mathrm{C}_{13} \mathrm{H}_{9} \mathrm{~N}_{3} \mathrm{~S}\end{array}$} \\
\hline & & & & & $\begin{array}{c}\mathrm{C} \\
65.25 \\
\end{array}$ & $\begin{array}{c}\mathrm{H} \\
3.79 \\
\end{array}$ & $\begin{array}{c}\mathrm{N} \\
17.56 \\
\end{array}$ \\
\hline $12 a$ & $10 a+11 a$ & beige & 33 & 134 & 65.12 & 4.02 & 18.01 \\
\hline $12 b$ & $10 a+11 b$ & beige & 31 & 160 & 65.54 & 4.05 & 17.70 \\
\hline 12c & $10 b+11 a$ & beige & 39 & 122 & 65.19 & 3.53 & 17.18 \\
\hline 12d & $10 b+11 b$ & beige & 25 & 171 & 65.10 & 3.38 & 17.08 \\
\hline
\end{tabular}

Table 6. ${ }^{1} \mathrm{H} \mathrm{NMR}\left(\mathrm{CDCl}_{3}, \delta \mathrm{ppm}, \mathrm{J} \mathrm{Hz}\right),{ }^{13} \mathrm{C} \mathrm{NMR}\left(\mathrm{CDCl}_{3}, \delta \mathrm{ppm}\right)$ data of 2,4-dipyridylthiazoles 12a-12d. Structure -chemical shift correlations were reported in the literature. ${ }^{34}$ See supporting info. Page 242

\section{2,5-Di(4-pyridyl)oxazole (14)}

$\boldsymbol{N}$-Isonicotinoyl-2-amino-1-(4-pyridyl)ethanone (13). Isonicotinoyl chloride (420 mg, $2 \mathrm{mmol}$ ) was added to an ice-cooled 2-aminoethanone $(\mathbf{6 b})(380 \mathrm{mg}, 2.1 \mathrm{mmol})$ solution in DMF (10 ml). The resulting mixture was allowed to warm to r.t., and was then stirred for $6 \mathrm{~h}$. The final mixture was evaporated to half of the volume at oil-pump vacuum, and was then quenched by water to give a solid, which was filtered and crystallized from ethanol. Yield $230 \mathrm{mg}$ (52\%), beige solid, m.p. $126{ }^{\circ} \mathrm{C} .{ }^{1} \mathrm{H} \mathrm{NMR}\left(\mathrm{CDCl}_{3}, \delta\right.$, ppm, J, Hz): 3.73 (d, 2H, $\mathrm{CH}_{2}-\mathrm{NHCO},{ }^{3} \mathrm{~J}=6.2$ ), 6.65 (br.t, $3 \mathrm{H}$, $\left.\mathrm{NH}_{3}{ }^{+}\right), 7.75-7.80$ (m, 4H, 3,5-H-Py $\left.{ }^{12}\right)$, 8.95-9.01 (m, 4H, 2,6H-Py ${ }^{12}$ ), 10.50 (br.s, 1H, NHCOPy). IR: 3380 (CONH); 1700, 1690 (C=O). MS (m/z, \%): 241(M+, 12), 106(PyCO, 100). Amidoketone $13(240 \mathrm{mg}, 1 \mathrm{mmol})$ was heated for $15 \mathrm{~min}$ to $170-180{ }^{\circ} \mathrm{C}$ on a Wood-bath. After cooling, the residue was quenched by ethanol, and was evaporated. The purification of solid by column chromatography $\left(\mathrm{CHCl}_{3}-\mathrm{MeOH} 15: 1\right)$ furnished $65 \mathrm{mg}(28 \%)$ of starting 13 and $14 \mathrm{mg}$ (6\%) of oxazole 14 as pale-yellow needles, m.p. $175{ }^{\circ} \mathrm{C} .{ }^{1} \mathrm{H} \mathrm{NMR}\left(\mathrm{CDCl}_{3}, \delta, \mathrm{ppm}, \mathrm{J}, \mathrm{Hz}\right): 7.55$ (d, 2H, 3,5H-Py $\left.{ }^{5}{ }^{3} \mathrm{~J}=5.5\right), 7.65$ (s, 3H, 4H-Oxaz), 7.86 (d, 2H, 3,5-H-Py $\left.{ }^{5},{ }^{3} \mathrm{~J}=5.5\right), 8.65$ (d, 2H, 
2,6H-Py $\left.{ }^{2},{ }^{3} \mathrm{~J}=5.5\right), 8.78$ (d, 2H, 2,6H-Py $\left.{ }^{2},{ }^{3} \mathrm{~J}=5.5\right)$. IR (neat): $2950(\mathrm{CH}) ; 1580$ (Py). MS (m/z, \%): 223(M+, 12), 78 (Py, 100).

Typical procedure for the preparation of $O$-pyridoyl pyridinecarbamidoxime $17 a-17 d^{11}$ Well-grind potassium carbonate $(4.3 \mathrm{~g}, 30 \mathrm{mmol})$ was added to a solution of pyridinecarbamidoxime $(2.75 \mathrm{~g}, 20 \mathrm{mmol})$ in dry acetone. The appropriate pyridoyl chloride ( $3.60 \mathrm{~g}, 20 \mathrm{mmol}$ ) was then added in a few portions. The resulting mixture was stirred overnight at r.t., then evaporated to dryness, and quenched with $30 \mathrm{ml}$ of water. This solution was extracted by DCM $(2 \times 50 \mathrm{ml})$, the organic phase was dried, evaporated and crystallized from aqueous alcohol to give O-acylated amidoximes 17. The yields, melting points and spectral data of 17a17d are presented in Table 7.

Table 7. Yields and spectral data of $O$-pyridoyl pyridinecarbamidoxime 17a-17d

\begin{tabular}{|c|c|c|c|c|c|}
\hline & $\begin{array}{c}\text { Starting } \\
\text { materials }\end{array}$ & Yield, \% & $\begin{array}{c}\text { m.p. } \\
{ }^{o} \mathrm{C}(\text { dec. })\end{array}$ & $\operatorname{IR}\left(v, \mathrm{CM}^{-1}\right)$ & ${ }^{1} \mathrm{H}$ NMR(DMSO-d 6 , $\delta$ ppm) \\
\hline $17 \mathbf{a}$ & $15 a+16 a$ & 76 & 192 & $\begin{array}{c}3150\left(\mathrm{NH}, \mathrm{NH}_{2}\right) \\
1710(\mathrm{COO})\end{array}$ & $\begin{array}{c}\text { 9.9(br.s., } 2 \mathrm{H}), 9.2(\mathrm{~m}, 2 \mathrm{H}), \\
\text { 8.82(m, 2H), 8,29(1H), } \\
8.10(1 \mathrm{H}), 7.48(1 \mathrm{H}), 7.41(1 \mathrm{H})\end{array}$ \\
\hline $17 b$ & $15 a+16 b$ & 82 & 197 & $\begin{array}{c}3150\left(\mathrm{NH}, \mathrm{NH}_{2}\right) \\
1710(\mathrm{COO})\end{array}$ & $\begin{array}{c}9.7(\text { br.s., } 2 \mathrm{H}), 9.1(\mathrm{~s}, 1 \mathrm{H}), 8.82(\mathrm{~d}, \\
2 \mathrm{H}), 8,68(1 \mathrm{H}), 8,32(1 \mathrm{H}), 8.05 \\
(1 \mathrm{H}), 7.62(\mathrm{~d}, 2 \mathrm{H}), 7.40(1 \mathrm{H})\end{array}$ \\
\hline 17c & $15 b+16 a$ & 74 & 193 & $\begin{array}{c}3150\left(\mathrm{NH}, \mathrm{NH}_{2}\right) \\
1710(\mathrm{COO})\end{array}$ & $\begin{array}{c}\text { 9.8(br.s., } 2 \mathrm{H}), 9.1(\mathrm{~s}, 1 \mathrm{H}), 8.88 \\
(\mathrm{~d}, 2 \mathrm{H}), 8,72(1 \mathrm{H}), 8.16(1 \mathrm{H}), 7.70 \\
(\mathrm{~d}, 2 \mathrm{H}), 7.28(1 \mathrm{H})\end{array}$ \\
\hline 17d & $15 b+16 b$ & 79 & 203 & $\begin{array}{c}3150\left(\mathrm{NH}, \mathrm{NH}_{2}\right) \\
1710(\mathrm{COO})\end{array}$ & $\begin{array}{c}9.8(\text { br.s., } 2 \mathrm{H}), 8.9-8.8(\mathrm{~m}, 4 \mathrm{H}) \\
7.68(\mathrm{~d}, 2 \mathrm{H}), 7.61(\mathrm{~d}, 2 \mathrm{H})\end{array}$ \\
\hline
\end{tabular}

Typical procedure for the preparation of 3,5-dipyridyl-1,2,4-oxadiazoles 18a-18d

A slurry of the appropriate O-pyridoyl pyridinecarbamidoxime $14(3 \mathrm{~g}, 12.4 \mathrm{mmol})$ in $50 \mathrm{ml}$ of dry toluene was refluxed with a Dean-Stark's trap for 4-6h (TLC control). After cooling, the mixture was evaporated to dryness, and the residue was crystallized from methanol. The yields, melting points and elemental composition data of 18a-18d are presented in Tables 8,9. 
Table 8. Yields and physical data of 3,5-dipyridyl-1,2,4-oxadiazoles 18a-18d

\begin{tabular}{|c|c|c|c|c|c|c|}
\hline & \multirow{2}{*}{$\begin{array}{l}\text { Starting } \\
\text { materials }\end{array}$} & \multirow{2}{*}{$\begin{array}{c}\text { Yield, } \\
\%\end{array}$} & \multirow{2}{*}{${ }^{\mathrm{m} . \mathrm{p} .}$} & \multicolumn{3}{|c|}{$\begin{array}{l}\text { Found: } \\
\text { Anal. Calcd. for } \\
\mathrm{C}_{12} \mathrm{H}_{8} \mathrm{~N}_{4} \mathrm{O}\end{array}$} \\
\hline & & & & $\begin{array}{c}C \\
65.28\end{array}$ & $\begin{array}{c}\mathrm{H} \\
3.60\end{array}$ & $\begin{array}{c}\mathrm{N} \\
24.99 \\
\end{array}$ \\
\hline $18 a$ & $17 a$ & 91 & 169 & 65.70 & 3.32 & 24.41 \\
\hline $18 b$ & $17 b$ & 85 & 176 & 64.93 & 3.71 & 24.22 \\
\hline $18 c$ & $17 c$ & 80 & 170 & 65.55 & 3.60 & 25.13 \\
\hline 18d & $17 d$ & 80 & 185 & 65.30 & 3.47 & 24.78 \\
\hline
\end{tabular}

Table 9. ${ }^{1} \mathrm{H} \mathrm{NMR}\left(\mathrm{CDCl}_{3}, \delta \mathrm{ppm}, \mathrm{J} \mathrm{Hz}\right),{ }^{13} \mathrm{C} \mathrm{NMR}\left(\mathrm{CDCl}_{3}, \delta\right.$ ppm$)$ data of 3,5-dipyridyl-1,2,4oxadiazoles 18a-18d. See supporting info. Page 243

Preparation of 2,5-dipyridyl-1,3,4-oxadiazoles 20a-20c. ${ }^{25}$ Pyridoyl chloride hydrochloride $(1.8 \mathrm{~g}, 10 \mathrm{mmol})$ was added to a well-stirred solution of 5-pyridyltetrazole $(1.5 \mathrm{~g}, 10 \mathrm{mmol})$ in $15 \mathrm{ml}$ of dry pyridine, preheated to $50{ }^{\circ} \mathrm{C}$. The resulting yellow mixture was cautiously heated to $75-90{ }^{\circ} \mathrm{C}$ and kept at this tempereture until the nitrogen gas evolution ceased. Then the mixture was cooled and filtered. The free base was isolated by consequent quenching with $\mathrm{NaOH}$ using a minimum water volume, extraction by DCM $(3 \times 30 \mathrm{ml})$, evaporation and crystallization from ethanol.

Under microwave activation, both reagents $(2 \mathrm{mmol}$ each) in $5 \mathrm{ml}$ pyridine were used. Irradiation was carried out in domestic MW-oven at $800 \mathrm{~W}$ power-level for $30 \mathrm{~s}$ period. The yields, melting points and elemental composition data of 20a-20c are presented in Tables 10,11. 
Table 10. Yields, melting points and elemental composition data of 2,5-dipyridyl-1,3,4oxadiazoles 20a-20c

\begin{tabular}{|c|c|c|c|c|c|c|c|}
\hline & \multirow{2}{*}{$\begin{array}{c}\text { Starting } \\
\text { materials }\end{array}$} & \multirow{2}{*}{$\begin{array}{c}\text { Yield, \% } \\
\text { heating/ } \\
\text { MW }_{\text {irr }}\end{array}$} & \multirow{2}{*}{$\begin{array}{l}\text { m.p. } \\
{ }^{\circ} \mathrm{C}\end{array}$} & \multirow[t]{2}{*}{$\begin{array}{l}\text { m.p. }{ }^{\circ} \mathrm{C} \\
\left(\text { lit. }^{24}\right) \\
20 \cdot \mathrm{HCl}\end{array}$} & \multicolumn{3}{|c|}{$\begin{array}{c}\text { Found: } \\
\text { Anal. Calcd. for } \\
\mathrm{C}_{12} \mathrm{H}_{8} \mathrm{~N}_{4} \mathrm{O} \\
\end{array}$} \\
\hline & & & & & $\begin{array}{c}\mathrm{C} \\
65.28 \\
\end{array}$ & $\begin{array}{c}\mathrm{H} \\
3.60 \\
\end{array}$ & $\begin{array}{c}\mathrm{N} \\
24.99 \\
\end{array}$ \\
\hline $20 a$ & $19 a+15 a$ & $70 / 78$ & 180 & $239(225)$ & 65.20 & 4.05 & 25.06 \\
\hline $20 \mathrm{~b}$ & $\begin{array}{l}19 a+15 b \\
19 b+15 a\end{array}$ & $\begin{array}{l}72 / 83 \\
88 / 90\end{array}$ & $\begin{array}{l}184 \\
184\end{array}$ & $229(221)$ & 65.31 & 3.88 & 24.79 \\
\hline $20 c$ & $19 b+15 b$ & $86 / 87$ & 188 & $251(250)$ & 65.29 & 3.63 & 25.08 \\
\hline
\end{tabular}

Table 11. ${ }^{1} \mathrm{H} \mathrm{NMR}\left(\mathrm{CDCl}_{3}, \delta\right.$ ppm, J Hz), ${ }^{13} \mathrm{C} \mathrm{NMR}\left(\mathrm{CDCl}_{3}, \delta\right.$ ppm $)$ data of 2,5-dipyridyl-1,3,4oxadiazoles 20a-20c. See supporting info. Page 244

3,5-Di(4-pyridyl)-4-(4-bromophenyl)-1,2,4-triazole (23). $N$-(4-Bromophenyl)isonicotinamide (21). The mixture of isonicotinoyl chloride hydrochloride $(3.6 \mathrm{~g}, 21 \mathrm{mmol})$ and 4-bromoaniline $(3.45 \mathrm{~g}, 20 \mathrm{mmol})$ in $30 \mathrm{ml}$ of dry DMF was heated at $75{ }^{\circ} \mathrm{C}$ over $30 \mathrm{~min}$. Then, the reaction mixture was poured onto $250 \mathrm{~g}$ of crushed ice and filtered. After recrystallization from alcohol $4.5 \mathrm{~g}(80 \%)$, a white solid was isolated, m.p. $214{ }^{\circ} \mathrm{C} .{ }^{1} \mathrm{H}$ NMR $\left(\mathrm{CDCl}_{3}, \delta\right.$, ppm, J, Hz): 7.40 (d, $\left.2 \mathrm{H}, 3,5-\mathrm{H}-\mathrm{Ph},{ }^{3} \mathrm{~J}=7.8\right), 7.65$ (d, 2H, 2,6-H-Ph, $\left.{ }^{3} \mathrm{~J}=7.8\right), 7.75$ (d, 2H, 3,5-H-Py, $\left.{ }^{3} \mathrm{~J}=6.1\right), 8.85$ (d, 2H, 2,6H-Py, ${ }^{3} \mathrm{~J}=6.1$ ), 11.30 (br.s, $\left.1 \mathrm{H}, \mathrm{NHCOPy}\right)$ IR: 3320 (CONH); $1700(\mathrm{C}=\mathrm{O})$.

$\mathrm{N}$-(4-Bromophenyl)-pyridin-4-yl-carbimidoyl chloride (22). Well-grind phosphorus pentachloride $(2.30 \mathrm{~g}, 11 \mathrm{mmol})$ was added to the slurry solution of amide $21(2.77 \mathrm{~g}, 10 \mathrm{mmol})$ in $20 \mathrm{ml}$ of dry toluene. The reaction mixture was heated on a boiling water-bath for $2 \mathrm{~h}$, then allowed to cool, and evaporated to dryness. The residue $(3.2 \mathrm{~g}, 96 \%)$ was washed with ether, vacuum-dried and resulted in a yellow solid, m.p. $162-168{ }^{\circ} \mathrm{C}$ (dec.), and was used immediately.

The appropriate triazole was synthesized in similar manner from 5-(4-pyridyl)- $1 \mathrm{H}$-tetrazole (19b) $(1.40 \mathrm{~g}, 9.5 \mathrm{mmol})$ and $22(3.15 \mathrm{~g}, 9.5 \mathrm{mmol})$. Pure product was isolated by column chromatography $\left(\mathrm{CHCl}_{3}-\mathrm{MeOH} 15: 1\right)$ to give $2.08 \mathrm{~g}(59 \%)$ of yellow solid, m.p. $284{ }^{\circ} \mathrm{C} .{ }^{1} \mathrm{H}$ NMR (CDCl3, $\delta$, ppm, J, Hz): 7.45 (d, 2H, 3,5-H-Ph, $\left.{ }^{3} \mathrm{~J}=7.5\right), 7.68$ (d, 2H, 2,6-H-Ph, ${ }^{3} \mathrm{~J}=7.5$ ), 8.05 (d, 2H, 3,5-H-Py, $\left.{ }^{3} \mathrm{~J}=6.3\right), 8.72$ (d, 4H, 2,6H-Py, $\left.{ }^{3} \mathrm{~J}=6.3\right)$. IR: $3320(\mathrm{CONH}) ; 1700(\mathrm{C}=\mathrm{O})$. ${ }^{13} \mathrm{C} \operatorname{NMR}\left(\mathrm{CDCl}_{3}, \delta\right.$, ppm,): 152.4, 147.1, 143.7, 136.0, 134.6, 124.2, 120.5, 119.1. Anal. Calcd. for $\mathrm{C}_{18} \mathrm{H}_{12} \mathrm{~N}_{5} \mathrm{Br}$ : C, 57.16; H, 3.20; N, 18.52. Found: C, 57.90; H, 3.68; N, 18.81 .

2,5-Di(4-pyridyl)-3H-naphtho[1,2-e]-1,3,4-triazepine (26b)

$\mathrm{N}$-(1-Naphthyl)isonicotinamide (24) was obtained in a similar manner from 1-naphtylamine $(2.85 \mathrm{~g}, 20 \mathrm{mmol})$ and isonicotinoyl choride hydrochloride $(3.6 \mathrm{~g}, 21 \mathrm{mmol})$ as coloreless needles. Yield $4.2 \mathrm{~g}(85 \%)$, m.p. $235{ }^{\circ} \mathrm{C}(\mathrm{EtOH})$, lit. m.p. $233-234{ }^{\circ} \mathrm{C}^{35} .{ }^{1} \mathrm{H} \mathrm{NMR}\left(\mathrm{CDCl}_{3}, \delta\right.$, 
ppm, J, Hz): 6.94-7.34 (4H, H-Naph), 7.65 (m, 1H, H-Naph), 7.70 (d, 2H, 3,5-H-Py, ${ }^{3} \mathrm{~J}=6.2$ ), 7.95 (m, 1H, H-Naph), 8.42 (m, 1H, H-Naph), 8.80 (d, 2H, 2,6H-Py, ${ }^{3} \mathrm{~J}=6.2$ ), 11.05 (br.s, $1 \mathrm{H}$, NHCOPy). IR: $3320(\mathrm{CONH}) ; 1700(\mathrm{C}=\mathrm{O})$.

$\mathbf{N}$-(1-Naphthyl)-pyridin-4-yl-carbimidoyl chloride hydrochloride (25) was obtained in the same way from $24(2.5 \mathrm{~g}, 10 \mathrm{mmol})$ and $\mathrm{PCl}_{5}(2.30 \mathrm{~g}, 11 \mathrm{mmol})$ as a yellow solid. Yield $2.92 \mathrm{~g}$ (96\%), m.p. $170-175^{\circ} \mathrm{C}$ (dec.). The compound was used without further characterization.

2,5-Di(4-pyridyl)-3H-naphtho[1,2-e]-1,3,4-triazepine (26b). $10 \mathrm{ml}$ of a water solution of $\mathrm{NaOH}(900 \mathrm{mg})$ was added to a slurry of 5-(4-pyridyl)- $1 H$-tetrazole (19b) $(1.40 \mathrm{~g}, 9.5 \mathrm{mmol})$ in $10 \mathrm{ml}$ of water. To this solution the solution of hydrochloride $25(2.90 \mathrm{~g}, 9.5 \mathrm{mmol})$ in $30 \mathrm{ml}$ of DCM, containing $1.2 \mathrm{ml}$ triethylamine and $50 \mathrm{mg}$ TEBAC, was added. The resulting mixture was then intensively stirred for $1 \mathrm{~h}$. The organic layer was separated and the aqueous layer was extracted by $10 \mathrm{ml}$ of DCM. The organic phases were combined and evaporated. The crude oily 2-(N-arylimidoil)tetrazole was placed in $20 \mathrm{ml}$ of dry toluene, and was heated at $90-100{ }^{\circ} \mathrm{C}$ for $1 \mathrm{~h}$. After cooling the reaction mixture was filtered and evaporated to dryness. The residue was crystallized from a benzene-ethyl acetate mixture to give triazepine $\mathbf{2 6}$ as brown solid. Yield 2.02 g (63\%), m.p. $228-231{ }^{\circ} \mathrm{C} .{ }^{1} \mathrm{H} \mathrm{NMR}\left(\mathrm{CDCl}_{3}, \delta\right.$, ppm, J, Hz): 7.45 (m, 2H, 4,6-H-Naph), 7.60 (d, 2H, 3,5-H-Py, ${ }^{3} \mathrm{~J}=6.0$ ), 7.81 (m, 2H, 3,7-H-Naph), 7.96-7.98 (2H, 5,8-H-Naph), 8.19 (d, 2H, 3,5-H-Py, ${ }^{3} \mathrm{~J}=6.0$ ), 8.69 (d, 2H, 2,6H-Py', ${ }^{3} \mathrm{~J}=6.0$ ), 8.84 (d, 2H, 2,6H-Py, ${ }^{3} \mathrm{~J}=6.0$ ), 10.30 (br.s, 1H, NH). IR: $3405(\mathrm{NH}) ; 1575$ (Py). Anal. Calcd. for $\mathrm{C}_{22} \mathrm{H}_{15} \mathrm{~N}_{5} \mathrm{C}, 75.63 ; \mathrm{H}, 4.33 ; \mathrm{N}, 20.04$. Found: C, 75.36; H, 3.89; N, 20.75.

3,5-Dipyridyl-1H-1,2,4-triazoles 29a-29c were synthesized according to the literature data ${ }^{17}$ in two steps via cyclocondensation of methyl pyridinecarbimidates with the appropriate pyridoylhydrazine. The spectral data of 20a-20c are presented in Table 12 .

Table 12. ${ }^{1} \mathrm{H} \mathrm{NMR}\left(\mathrm{CDCl}_{3}, \delta \mathrm{ppm}, \mathrm{J} \mathrm{Hz}\right),{ }^{13} \mathrm{C} \mathrm{NMR}\left(\mathrm{CDCl}_{3}, \delta\right.$ ppm $)$ data of 3,5-Dipyridyl-1H1,2,4-triazoles 27a-27c. See supporting info. Page 245

\section{Supplementary information is Available}

\section{Acknowledgements}

We thank the Russian Foundation for Basic Researches for the financial support (grant \# 03-0332401)

\section{References and Footnotes}

1. Kitagawa, S.; Kitaura, R.; Noro, S. Angew. Chem., Int. Ed. 2004, 43, 2334. 
2. Janiak, C. J. Chem. Soc., Dalton Trans. 2003, 2071.

3. Blake, A. J.; Champness, N. R.; Crew, M.; Parsons, S. New J. Chem. 1999, 23, 13.

4. Blake, A. J.; Champness, N. R.; Hubberstey, P.; Li, W.-S.; Wittersby, M. A.; Schroeder M. Coord. Chem. Rev. 1999, 183, 117.

5. Klingele, M.; Brooker, S. Coord. Chem. Rev. 2003, 241, 119.

6. Huang, Z.; Song, H.-B.; Du, M.; Chen, S.-T.; Bu, X.-H.; Ribas, J. Inorg. Chem. 2004, 43, 931.

7. Zhang, X.-M.; Fang, R.-Q.; Wu, H.-S. Cryst. Eng. Comm. 2005, 7, 96.

8. Nakano, K.; Suemura, N.; Yoneda, K; Kawata, S.; Kaizaki, S. J. Chem. Soc., Dalton Trans. 2005, 740.

9. Ferles, M.; Liboska, R.; Trska, P. Coll. Czech. Chem. Commun. 1990, 55, 1228.

10. Churakov, A. V.; Kuz'mina, L. G.; Nuriev, V. N.; Vatsadze, S. Z.; Zyk, N. V. Acta Cryst. 2004, E60, 1231.

11. Churakov, A. V.; Kuz'mina, L. G.; Nuriev, V. N.; Vatsadze, S. Z.; Zyk, N. V. to be published elsewhere.

12. Vatsadze, S. Z.; Nuriev, V. N.; Lescheva, I. F.; Zyk N.V. Russ. Chem. Bull., Int. Ed. 2004, 54,849 .

13. Cymerman-Craig, J.; Willis, D. J. Chem. Soc. 1955, 4315.

14. LaMattina, J. L.; Suleske, R. T. Org. Synth. 1990, 60-64, 149.

15. Clemo, G.R.; Holmes, T.; Crace, C.L. J. Chem. Soc. 1938, 753.

16. Hatch, M. J.; Cram, D. J. J. Am. Chem. Soc. 1953, 75, 38.

17. Browne, E. Austr. J. Chem. 1975, $28,2543$.

18. Dornow, A.; Machens, H.; Brunochen, K. Chem. Ber. 1951, 84, 147.

19. Cassar, L.; Panossian, S.; Giordano, C. Synthesis 1978, 917.

20. Menasse, R.; Klen, G.; Erlenmeyer, H. Helv. Chim. Acta 1955, 38, 1289.

21. Clarke, K. J. Chem. Soc. 1954, 4251.

22. Delaby, R.; Reynaud, P.; Tupin, Th. Bull. Soc. Chim. France 1957, 714.

23. Pachamia, V.; Parikh, A. J. Ind. Chem. Soc. 1988, 65, 357.

24. Pachamia, V.; Parikh, A. J. Ind. Chem. Soc. 1989, 66, 250.

25. Huisgen, R.; Sauer, J.; Sturm, H. Angew. Chem. 1958, 70, 272.

26. Singh, B.; Lesher, G. Y. Synthesis 1978, 829.

27. Fabbrini, L. Farmaco Ed. Sci. 1954, 9, 603.

28. Becker, T. Magn. Reson. Chem. 1993, 31, 107.

29. Libick, K. Chem. Ber. 1994, 127, 2373.

30. Howell, K. J. Org. Magn. Reson. 1980, 13, 436.

31. Clemo, G.; Holmes, T. J. Chem. Soc. 1934, 1739.

32. Molsen, R.T. J. Med. Chem. 1993, 36, 3350.

33. Menasse, R.; Klen, G.; Erlenmeyer, H. Helv. Chim. Acta 1955, 38, 1289.

34. Sahn, V.; Pachari, T. J. Het. Chem. 1991, 28, 673.

35. Epsztajn, J; Bieniek, A;Płotka, M. W.; Suwald, K. Tetrahedron 1989, 45, 7469. 